\title{
THE SURFACE WATERS THAT FLOW TO LAKE OHRID AND ROLE OF DIATOMS IN BIOLOGICAL MONITORING
}

\author{
Elona Bahiti ${ }^{1}$, Lirika Kupe ${ }^{2 *}$ \\ ${ }^{1}$ University of "Alekander Xhuvani", Elbasan, Albania; \\ ${ }^{2 *}$ Agricultural University of Tirana, Faculty of Agriculture and Environmental, Department of Agronomy Sciences, \\ Tirana, Albania;
}

"Corresponding author Lirika Kupe, e-mail: "lirika_kupe@yahoo.com; elonabahiti@gmail.com;

Received February 2019; Accepted March 2019; Published April 2019;

DOI: https://doi.org/10.31407/ijees9204

UOI license: http://u-o-i.org/1.01/ijees/55032019

\begin{abstract}
Ohrid Lake is one of the oldest lakes in the world, formed about 2-3 million years ago. Many of lakes of the globe are about 10,000 to 45,000 thousand years old and formed during the glacial period. In an old lake, with hills and mountains that separated them from other waters, a whole collection of plants and animals is developed. Lake Ohrid is located at a height of $695 \mathrm{~m}$, with a surface of $358.2 \mathrm{~km}^{2}$ and a coastline of $87.5 \mathrm{~km}$. About $2 / 3$ of the lake is in the North Macedonian part and 1/3 belongs to the Albanian side. It represents an exceptional source of water, the great biological diversity and the endemic species that are presently threatened by many factors. Most of the Ohrid Lake basin is formed by tectonic forces. At a later stage of the alpine oogenesis the holes of Ohrid, Prespa and Debarca are formed. The Ohrid Lake itself is formed on Bilisht-Korça-Debarca. As a geomorphologic characteristic of the catchment basin we mention abrasive formations (rugged rocks, bare rocks and rocks and subsoil), river formations (river valleys, river beds, erosive and accumulative terraces) karstic formations (cracks, water holes, pits and fields karstic surface as well as holes and underground holes). Biomonitoring is the use of biological indicators as assessors of environmental change. Since, chemical compounds of the rivers pass through mass flows over a short period of time, chemical monitoring gives an instantaneous water quality picture only for the sampling moment. In Albania, biological monitoring based in diatoms, for the first time is carried out in Albanian rivers (fresh water), the data are presented by Miho et al., (2005); on PhD thesis by Kupe L., (2006). After then had continued with further studies in the area of ecological (diatoms) assessment of fresh and marshes water.
\end{abstract}

Keywords: surface water, biological monitoring, sources, benthic diatoms. 